Hum. Hered. 1991;41:I-VI

\title{
Contents, Vol. 41, 1991
}

\section{Editor}

J. Ott, New York, N.Y.

Associate Editors

L. Beckman, Umeå C.R. Cloninger, St. Louis, Mo. P.M. Conneally, Indianapolis, Ind. H. Hoehn, Würzburg

Editorial Board

K. Berg, Oslo

L.L. Cavalli-Sforza, Stanford, Calif.

A. de la Chapelle, Helsinki

J. Dausset, Paris

T.J. David, Manchester

B. Dutrillaux, Paris

F.C. Fraser, Montreal

N. Freire-Maia, Curitiba

J. Frézal, Paris

R. Grubb, Lund PA. Jacobs, Salisbury Margareta Mikkelsen, København F. Mitelman, Lund

N.E. Morton, Southampton

J. Mohr, København

A.E. Mourant, London

J.V. Neel, Ann Arbor, Mich.

U. Pettersson, Uppsala

Marianne Rasmuson, Umeå

D.L. Rimoin, Los Angeles, Calif.

L.D. Sanghvi, Bombay

M. Siniscalco, Sassari

F. Vogel, Heidelberg

DJ. Weatherall, Oxford

R.L. White, Salt Lake City, Utah

M. Whittaker, Exeter

KARGER

Contents Vol. 41,1991

No. 1 Original Paper

New Mutation versus Exclusion at the Alpha-1-Antitrypsin Locus: A Multifaceted Approach in a Problematical Paternity Case

Bender, K.; Kasulke, D.; Mayerovà, A.; Hummel, K.; Weidinger, S.; Epplen, J.T.; 
Wienker, T.F 1

Family Distances as a Measure of Hidden Consanguinity. A Reappraisal

Swaving, J.; Groenewegen, A.; Kamstra, A.; te Meerman, G.J.; ten Kate, L.P 12

Characterization of Glucose-6-Phosphate Dehydrogenase Variants in the Sudan - Including Gd101^0" "1, a Hyperactive Slow Variant

Saha, N.; Samuel, A.P.W 17

Phosphoglucomutase-1 Polymorphism among Chinese in Taiwan

Lin-Chu, M.; Loo, J.H.; Hayward, M.A 22

Patterns of Sickle Cell, Thalassaemia and Glucose-6-Phosphate Dehydrogenase Deficiency

Genes in North-Western Saudi Arabia

El-Hazmi, M.A.F.; Jabbar, F.A.; Al-Faleh, F.Z.; Al-Swailem, A.R.; Warsy, A.S 26

Blood Groups in the Chueta Community (Majorcan Jews)

Picornell, A.; Castro, J.A.; Ramon, M.M 35

Serum Protein Polymorphisms in the Population of South Yemen

Spitsyn, V.A.; Titenko, N.V.; Gokhman, I.I.; Bogdanova, V.I.; Chistov Y. K

Apolipoprotein A-IV Polymorphism in Singapore Ethnic Groups

Saha, N $\quad 47$

Distribution of Group-Specific Component/Vitamin-D-Binding Protein Subtypes in Saudi

Arabia

Degheishem, S.M.; Sedrani, S.H.; Van Baelen, H; Bouillon, R.; Duhaiman, A.S. ... 53

Restriction Fragment Length Polymorphisms of Three Collagen Genes in Russians and

Buryats

Sokolov, B.P.; Dzemelinski, V.V.; Kalinin, V.N 57

Short Communications

A Simplified Method for Screening the Apolipoprotein E Polymorphism

Eichner, J.E.; Kuller, L.H.; Ferrell, R.E.; Kamboh, M.I 61

Further Evidence of Cystic Fibrosis Heterogeneity in Southern Europe

Kalaydjieva, L.; Plageras, P.; Horst, J 65

Genomic Clone OS-2 (D10S20) Detects Different Restriction Fragment Length Polymor

phisms in Caucasians and Orientals for Both Hindl $\prod$ and TaqI

Parsian, A.; Devor, E.J 68

Contents HI

Is the Genotoxic Effect of Arsenic Mediated by Oxygen Free Radicals?

Nordenson, I.; Beckman, L 71

Alpha-2-HS-Glycoprotein Phenotype Frequencies in Cook Islanders

Abe, S.; Kurisaki, E.; Mizusawa, I.; Hiraiwa, K 74

No. 2 Original Paper

Immunological Studies of Families Segregating the Silent Gene for Plasma Cholines-

terase

Whittaker, M.; Jones, J.W.; Braven, J

77

High Prevalence of Haemoglobin E in Three Populations of the Malda District, West

Bengal, India

Das, M.K.; Dey, B.; Roy, M.; Mukherjee, B.N 84

Genetic Polymorphism of Alpha-2-HS-Glycoprotein: Four New Alleles and Allele Frequencies in Japanese

Fukuma, Y.; Kashimura, S.; Nakano, B.; Umetsu, K.; Yuasa, I.; Nakasono, 1 
Acid Phosphatase, Adenosine Deaminase and Esterase D Polymorphisms in the Spanish Basque Population

Aguirre, A.I.; Vicario, A.; Mazón, L.I.; Pancorbo, M.M. de; Estomba, A.; Lostao, C. . 93 CHEl UF Serum Cholinesterase Phenotype in Whites and Non-Whites from Southern

Brazil as Determined by a New Method

Alcantara, V.M.; Chautard-Freire-Maia, E.A.; Culpi, L 103

Familial Aggregation of Lipids and Lipoproteins in Families Ascertained through Random and Nonrandom Probands in the Iowa Lipid Research Clinics Family Study

Rice, T.; Vogler, G.P.; Perry, T.S.; Laskarzewski, P.M.; Rao, D.C 107

A New PstI Restriction Fragment Lenght Polymorphism (RFLP) of Placental Alkaline

Phosphatase. RFLP Haplotypes and Correlation with Electrophoretic Types

Beckman, G.; Beckman, L.; Kivelä, A.; Millán, J.L.; Sikström, C 122

C1R Subcomponent Polymorphism in Japanese: Description of a New Allele

Kido, A.; Komatsu, N.; Kimura, Y; Oya, M 129

Phosphoglucomutase Phenotyping among Chinese in Taiwan

Lin-Chu, M.; Loo, J.-H.; Hayward, M.A 134

Short Communication

Plasminogen Polymorphism in Libyans: Description of a New Rare Variant

Sebetan, I.M 138

No. 3 Original Paper

Hereditary Disorders in Saguenay-Lac-St-Jean (Quebec, Canada)

De Braekeleer, M 141

Association between the Acid Phosphatase 1 and Adenosine Deaminase Systems in a Bra zilian Sample

Engrácia, V.; Mestriner, M.A.; Cabello, P.H.; Krieger, H 147

Impact of Heredity in Myopia

Teikari, J.M.; O’Donnell, J.; Kaprio, J.; Koskenvuo, M 151

Population Studies in Northern Sweden. XVII. Estimates of Finnish and Saamish

Influence

Nylander, P.-O.; Beckman, L 157

IV Contents

Founder Effect in Familial Hyperchylomicronemia among French Canadians of Quebec

De Braekeleer, M.; Dionne, C; Gagné, C; Julien, P.; Brun, D.; Ven Murthy, M.R.;

Lupien, P.-J 168

Forensic Applications of Molecular Genetic Analysis: An Italian Collaborative Study on

Paternity Testing by the Determination of Variable Number of Tandem Repeat DNA

Polymorphisms

Gasparini, P.; Mandich, P.; Novelli, G.; Bellone, E.; Sangiuolo, F.; De Stefano, F.;

Potenza, L.; Trabetti, E.; Marigo, M.; Pignatti, P.F.; Dallapiccola, B.; Ajmar, F. ... 174 Protease

Inhibitor Frequencies: Is There a Deficit of M Subtype Heterozygotes?

Whitfield, J.B 182

DNA Polymorphism and Linkage Disequilibrium within the Apolipoprotein CП Locus on

Human Chromosome 19

MacKenzie, A.E.; MacLeod, H.L.; Leblond, S.C; Monteith, N.; Lahey, D.; Komeluk, R.G. 188

Segregation Distortions of the ABO and Rh Systems in Malformed Newborns

Cifuentes, L.; Nazer, J.; Valenzuela, C.Y 195 
Transferrin Types in Different Ethnic Groups of the USSR and Mongolia

Titenko, N.V.; Spitsyn, V.A.; Alekseeva, T.I201

Short Communication

Polymorphism of Complement Component I in Mongoloid Populations: A New Genetic

Variant IF A2

Ding, M.; Umetsu, K.; Yuasa, I.; Nakamura, S.; Choi, W.Y.; Suzuki, T 206

No. 4 Original Paper

Frequency of HLA-DQA1 Alleles in the Japanese Population

Tamaki, K; Yamamoto, T.; Uchihi, R.; Katsumata, Y.; Kondo, K; Mizuno, S.; Kimura,

A.; Sasazuki, T 209

Population Genetics of Alpha-1-Antitrypsin Polymorphism in US Whites, US Blacks and African Blacks

De Croo, S.; Kamboh, M.I.; Ferrell, R.E 215

Localization of Human Glandular Kallikrein-1 Gene to Chromosome 19q13.3-13.4 by in situ Hybridization

Qin, H.; Kemp, J.; Yip, M.-Y.; Lam-Po-Tang, P.R.L.; Morris, B.J 222

A Japanese Family with Unusual Segregation of GM Phenotype: A GM Silent Allele?

Kishida, T.; Tamaki, Y.; Wakasugi, C 227

Duffy Blood Groups and Malaria in the Ao Nagas in Nagaland, India

Kar, S.; Seth, S.; Seth, P.K 231

Genetic Polymorphisms in Southwest Alaskan Eskimos

Petersen, G.M.; Ward, J.I.; Terasaki, P.I.; Schanfield, M.S.; Ferrell, R.E.; Scott, E.M.;

Park, M.S 236

A Population Genetic Study in Finland: Comparison of the Finnish- and Swedish-Speaking Populations

Virtaranta-Knowles, K; Sistonen, P.; Nevanlinna, H.R 248

Serum Paraoxonase Polymorphism in Three Populations of Southeast Asia

Roy, A.C.; Saha, N.; Tay, J.S.H.; Ratnam, S.S 265

Polymorphisms of Serum Proteins in Japanese Patients with Vascular Diseases. I. Factor

XIIIB, Plasminogen and Complement Types in Primary Varicose Veins

Mizutani, K.; Nishimukai, H.; Yasugi, T.; Iwahashi, K; Tsunekawa, K; Shinomiya, T. 270

Contents

$\mathrm{V}$

Short Communications

Monomorphism of Formaldehyde Dehydrogenase in Different Populations

Benkmann, H.G.; Agarwal, D.P.; Saha, N.; Goedde, H.W 276

Distribution of Common Phenotypes of Sperm Diaphorase (DIA3) in the Polish Popula

tion

Pawlowski, R 279

No. 5 Original Paper

DNA Polymorphisms of the Apolipoprotein AI/CIII/AIV Gene Cluster Inñuence Plasma

Cholesterol and Triglyceride Levels in the Mayans of the Yucatan Peninsula, Mexico

Ahn, Y.I.; Valdez, R.; Reddy, A.P.; Cole, S.A.; Weiss, K.M.; Ferrell, R.E 281

The Lewis Blood Group System among Chinese in Taiwan

Broadberry, R.E.; Lin-Chu, M 290

D- and Dc- Gene Complexes in the Coloureds and Blacks of Natal and the Eastern Cape 
and Blood Group Phenotype and Gene Frequency Studies in the Natal Coloured Population Moores, P.; Vaaja, U.; Smart, E 295

Genetic Polymorphism of Alpha-2-HS-Glycoprotein in a Spanish Population

Alonso, A.; Weidinger, S.; Visedo, G.; Sancho, M.; Fernandez-Piqueras, J 305

Phosphoglucomutase-1 Subtypes in Two Populations in Adriatic Islands: Presence of

PGM1*W3 (PGM 1*7+) Allele

Borot, N.; Arnaud, J.; Rudan, P.; Chaventré, A.; Sevin, J 309

Linkage Disequilibrium and Linkage Information from One-Child Families

Tai, J.J.; Song, W.H 316

HLA Phenotype and Haplotype Frequencies in the Cantabria (Middle North Spain) Population

Calvet, R.; Pastor, J.M.; Fernandez, R.; Zubizarreta, A.; Romero, J.L 324

The C5 Isozyme of Serum Cholinesterase and Adult Weight

Chautard-Freire-Maia, E.A.; Primo-Parmo, S.L.; Picheth, G.; Lourenço, M.A.C.;

Vieira, M.M 330

Alpha-1-Antitrypsin (PI) Polymorphism in France, with Special Regard to the PI*Z Allele

Sesboüé, R.; Martin, J.P 340

Haptoglobin Phenotypes in Diabetes mellitus and Diabetic Retinopathy

Chandra, T.; Lakshmi, CM.; Padma, T.; Vidyavathi, M.; Satapathy, M

347

Erratum $\quad 351$

Announcement $\quad 352$

No. 6 Original Paper

A Further Polymorphism of the Gd Locus for Glucose-6-Phosphate Dehydrogenase Present among Blacks (Nigerians) and Apparently Absent among Caucasoids: The Quantitative Isoelectrophoretic Variation of the $\mathrm{Gd}+$ Allele

Modiano, G.; Ciminelli, B.M.; Malaspina, P.; Santolamazza, P.; Sedran, L.; Meloni, T.;

Forteleoni, G.; Mela, G 353

Evidence Supporting Tight Linkage of X-Linked Emery-Dreifuss Muscular Dystrophy to the Factor VIIL·C Gene

Wehnert, M.; Machill, G.; Grimm, T.; Janka, M.; Camman, R.; Schroder, W.; Herr

mann, F.H 364

VI

Contents

Estimate of the Intrafamilial Correlation for Serum Creatine Kinase and Pyruvate Kinase in Females at Risk for Duchenne and Becker Muscular Dystrophies

Rabbi-Bortolini, E.; Dal Colletto, G.M.D.; Passos-Bueno, M.R.; Vainzof, M.; Rapaport, D.; Zatz, M 370

Inbreeding in Saguenay-Lac-St-Jean (Quebec, Canada): A Study of Catholic Church Dis pensations 1842-1971

De Braekeleer, M.; Ross, M 379

Human Enzyme Polymorphism in the Canary Islands. IV. Eastern Islands

Perez, M.J.; Hierro, J.M.; Marrero, M.J.; Gonzalez, A.M.; Cabrera, V.M 385

Population Genetics of the Malmö Polymorphism of Coagulation Factor IX

Wallmark, A.; Kunkel, G.; Mouhli, H.; Bosco, J.; Ljung, R.; Nilsson, I.M.; Graham, J.B. 391

Factor B (BF) Allotypes and Multiple Sclerosis in North-East England

Papiha, S.S.; Duggan-Keen, M.; Roberts, D.F 397 
Allele Frequencies of Human Complement Factor I in a Sample from Iwate, Northern Japan, with the Description of Geographical Cline

Nakamura, S.; Omoto, K.; Sawaguchi, A 403

Short Communications

Distribution of Glm(1), Glm(2) and G3m(5) Allotypes in Aragon

Almuzara, I.; Martinez Jarreta, B.; Castellano, M 409

Phosphoglucomutase-1 (PGMl) W23 and W26 Variants detected in the Taiwanese Chinese

Population

Hayward, M.A.; Lin-Chu, M 411

Author Index 413

Subject Index 415

S. Karger $\cdot$ Medical and Scientific Publishers

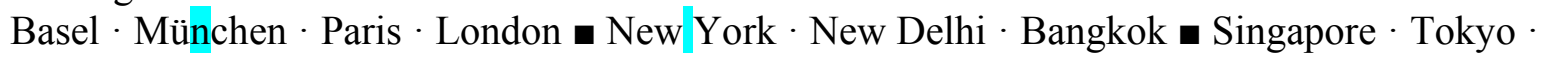
Sydney

Drug Dosage

The authors and the publisher have exerted every effort to ensure that drug selection and dosage set forth in this text are in accord with current recommendations and practice at the time of publication. However, in view of ongoing research, changes in government regulations, and the constant flow of information relating to drug therapy and drug reactions, the reader is urged to check the package insert for each drug for any change in indications and dosage and for added warnings and precautions. This is particularly important when the recommended agent is a new and/or infrequently employed drug.

All rights reserved.

No part of this publication may be translated into other languages, reproduced or utilized in any form or by any means, electronic or mechanical, including photocopying, recording, microcopying, or by any information storage and retrieval system, without permission in writing from the publisher or, in the case of photocopying, direct payment of a specified fee to the Copyright Clearance Center (see 'Information for Readers and Subscribers').

(C) Copyright 1991 by

S. Karger AG, P.O. Box, CH-4009 Basel (Switzerland) Printed in Switzerland on acid-free paper by Basler Zeitung + Basler Nachrichten AG, Basel 